\title{
FAKTOR-FAKTOR YANG MEMPENGARUHI VOLUME EKSPOR UDANG PUTIH (PENAEUS INDICUS) INDONESIA KE HONGKONG SERTA IMPLIKASI KEBIJAKANNYA \\ Betrix Silitonga ${ }^{1}$, Manuntun Parulian Hutagaol ${ }^{2}$ \\ ${ }^{1}$ Mahasiswa Ilmu Ekonomi, FEM IPB \\ ${ }^{2}$ Staff Pengajar FEM IPB
}

\begin{abstract}
This study aimed to analyze the factors that affect the volume of Indonesian exports of white shrimp (Penaeus indicus) to Hongkong and to formulate policies that can increase the volume of exports. Ordinary Least Square method (OLS) is used to analyze the factors that affect the volume of Indonesian white shrimp exports to Hongkong by time series data (time series) period of the last 24 years (1990 until 2013). All independent variables that have significant influence on the volume of Indonesian exports of white shrimp, which are: Hongkong population, Hongkong GDP per capita constant 2005, the nominal selling price of white shrimp Indonesia to Hongkong, the nominal selling price of white shrimp competitor to Hongkong, the nominal exchange rate of the Indonesian to Hongkong and Indonesian economic crisis in 1998 (dummy).
\end{abstract}

Key words: Hongkong, Ordinary Least Square (OLS), the export volume, the white shrimp (Penaeus indicus)

\section{PENDAHULUAN}

\section{Latar Belakang}

Negara Indonesia memiliki spesies udang yang sangat beragam, salah satunya terdapat jenis udang putih atau Penaeus indicus. Udang putih merupakan spesies udang laut berukuran sedang sekitar $22 \mathrm{~cm}$ yang hidup di laut secara berkelompok dengan jumlah besar. Udang putih yang berukuran relatif sedang banyak diminati konsumen kelas menengah ke atas dan lebih tahan terhadap perubahan kondisi perairan, bebas stress, toleran dengan perubahan suhu yang luas serta memiliki tingkat kelangsungan hidup tinggi. Udang jenis ini memiliki nilai jual yang lebih tinggi dibandingkan jenis udang lainnya karena terdapat sumber gizi yang tinggi didalamnya.

Berdasarkan Ditjen Perikanan Budi daya Kementerian Kelautan dan
Perikanan (2014), produksi perikanan budi daya udang dari tahun 2010 sampai tahun 2014 memiliki kecenderungan semakin naik yaitu sebesar 380972 ton di tahun 2010 dan 592219 ton di tahun 2014. Produksi udang secara umum terus meningkat dari tahun 2010 sampai tahun 2014 seperti yang termuat dalam Tabel 1. Kenaikan rata-rata udang tersebut selama 5 tahun terakhir sebesar $13,83 \%$ per tahun.

Produksi udang putih relatif kecil dibandingkan produksi udang jenis lainnya, tetapi peluang pengembangan budi daya udang putih relatif lebih besar dibandingkan udang jenis lainnya. Besar peluang budi daya udang putih dikembangbiakkan sekitar 75,64\% sampai $98,57 \%$ dari potensi lahan masing-masing jenis budi daya udang putih yang tersedia (Ditjen PT KKP 2013).

Kontribusi udang putih terhadap ekspor sub sektor perikanan sangat 
penting karena udang putih memiliki peluang pengembangan budi daya sangat besar dibandingkan budi daya udang jenis lainnya dan nilai jual udang putih relatif lebih mahal sehingga dapat memberi dampak terhadap surplus net ekspor. Cina ${ }^{*}$ merupakan negara tujuan utama ekspor udang putih Indonesia dengan tingkat konsumsi udang putih yang tinggi setiap tahunnya.

Indonesia merupakan salah satu negara yang berpeluang sangat besar dalam memasok udang putih untuk memenuhi permintaan pasar di dunia. Produksi udang putih yang dikembangkan oleh Indonesia setiap tahunnya dapat memberikan dampak terhadap pertumbuhan ekonomi Indonesia, yaitu: terbukanya lapangan pekerjaan yang mampu mengurangi angka kemiskinan dan pengangguran, memperbesar kontribusi ekspor terhadap surplus neraca perdagangan serta meningkatkan investasi di sektor perikanan.

Tabel 1 Produksi udang Indonesia tahun 2010 sampai tahun 2014

\begin{tabular}{lrrrrr}
\hline \multicolumn{1}{c}{ Komoditi } & 2010 & 2011 & 2012 & 2013 & $2014^{*}$ \\
\hline Volume Produksi (ton) & 380972 & 401154 & 415703 & 638955 & 592219 \\
Udang Windu & 125519 & 126157 & 117888 & 171583 & 126595 \\
Udang Vaname & 206578 & 246420 & 251763 & 390278 & 411729 \\
Udang Putih & 48875 & 28577 & 46052 & 77094 & 53895 \\
Volume Ekspor (ton) & 145092 & 158062 & 162068 & 162410 & 141042 \\
\hline
\end{tabular}

Sumber: Ditjen Perikanan Budi daya, KKP (2014)

Kontribusi sub sektor perikanan terhadap Produk Domestik Bruto (PDB) sektor pertanian yang relatif kecil cenderung mengalami peningkatan setiap tahun. Sub sektor perikanan merupakan salah satu sub sektor yang memberikan kontribusi terhadap sektor pertanian, yaitu sebesar $4,78 \%$ pada Pelita I dan meningkat menjadi 7,45\% di Pelita V (Oktariza, 2000). Potensi sub sektor perikanan mampu memberikan pertumbuhan ekonomi pada sektor pertanian sehingga perlu dilakukan upaya yang maksimal terhadap lahan budi daya udang putih untuk meningkatkan PDB sektor pertanian.

Pada Gambar 1 menunjukkan bahwa kecenderungan volume ekspor udang putih Indonesia ke dunia tidak stabil setiap tahunnya. Kecenderungan volume ekspor udang putih Indonesia ke dunia yang semakin meningkat dari tahun 1991 sampai tahun 1993, tahun 1994 sampai tahun 1995, tahun 1996 sampai tahun 1999, tahun 2000 sampai tahun 2001, tahun 2003 sampai tahun 2007 dan tahun 2010 sampai tahun 2012. Volume ekspor udang putih Indonesia ke dunia semakin menurun yang terjadi pada tahun 1990 sampai tahun 1991, tahun 1993 sampai tahun 1994, tahun 1995 sampai tahun 1996, tahun 1999 sampai tahun 2000, tahun 2001 sampai tahun 2003, tahun 2007 sampai tahun 2010 dan tahun 2012 sampai tahun 2013.

Selama periode observasi, volume ekspor udang putih Indonesia ke dunia paling besar terjadi pada tahun 1999 yang mencapai $2408041 \mathrm{~kg}$. Tahun 1999 merupakan pencapaian tertinggi volume ekspor udang putih Indonesia ke dunia tetapi jumlah tersebut tidak konsisten untuk periode selanjutnya setelah terjadinya krisis ekonomi tahun 1998 di Indonesia. Titik terendah volume ekspor udang putih Indonesia ke dunia terjadi pada tahun 1991 yang mencapai $49143 \mathrm{~kg}$ (UN Comtrade, 2013). 
Pemanfaatkan potensi dan peluang pasar komoditi udang putih di Indonesia masih tergolong rendah meskipun setelah terjadinya krisis ekonomi tahun 1998 volume ekspor udang putih Indonesia semakin meningkat dibandingkan tahun sebelumnya. Melemahnya rupiah terhadap dolar Amerika atau depresiasi rupiah akibat krisis ekonomi tahun 1998 berimplikasi terhadap volume ekspor udang putih Indonesia sehingga harga udang putih Indonesia dinilai relatif lebih murah dibandingkan harga udang putih negara lainnya.
Hongkong merupakan negara tujuan utama ekspor udang putih Indonesia karena kecenderungan nilai dan volume ekspor udang putih Indonesia yang tinggi setiap tahunnya ke negara tersebut. Pada tahun 1990 sampai tahun 1992, tahun 1993 sampai tahun 1995, tahun 1996 sampai tahun 1997, tahun 1998 sampai tahun 1999, tahun 2000 sampai tahun 2001, tahun 2003 sampai tahun 2007 dan tahun 2008 sampai tahun 2009 volume ekspor udang putih Indonesia semakin bertambah ke negara Hongkong (UN Comtrade, 2013).

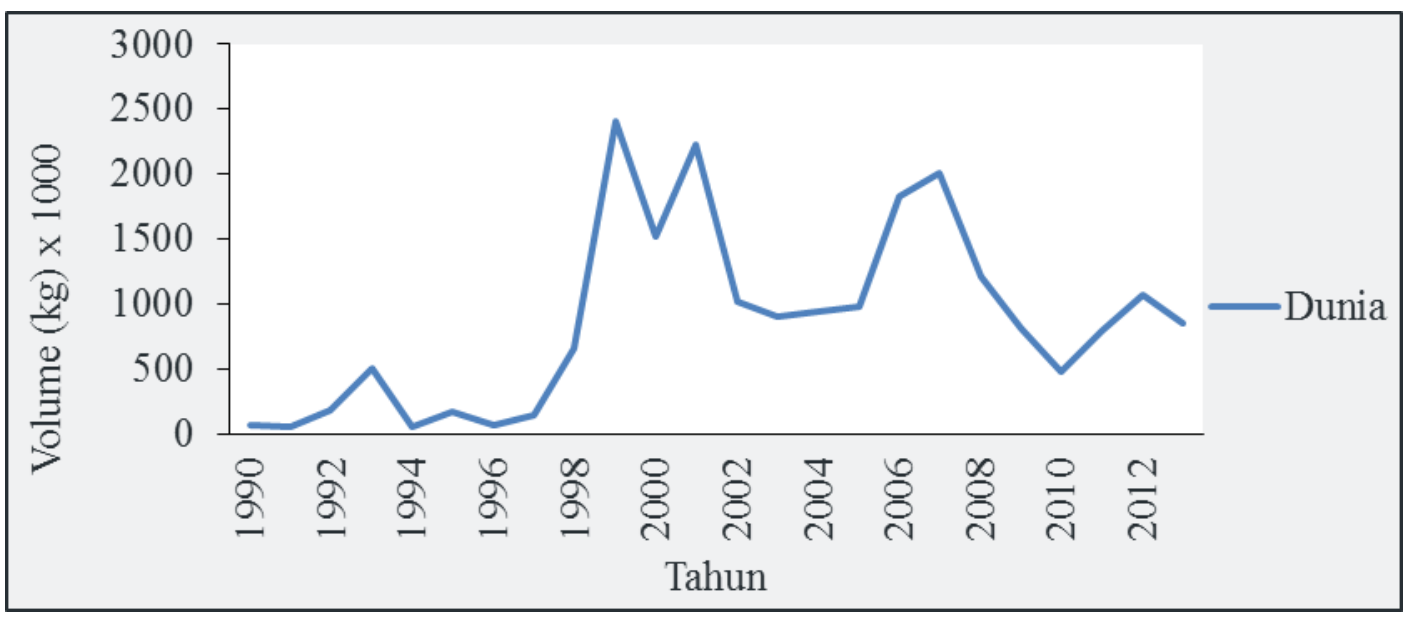

Sumber: UN Comtrade, 2013 (diolah)

Gambar 1 Pertumbuhan ekspor udang putih Indonesia ke dunia

Berdasarkan UN Comtrade (2013), volume ekspor udang putih Indonesia ke negara Hongkong meningkat sejak tahun 1990 sampai tahun 1992, yaitu sebesar: $11500 \mathrm{~kg}$ menjadi $100625 \mathrm{~kg}$. Pada tahun 1993 sampai tahun 1995 volume ekspor udang putih Indonesia ke negara Hongkong meningkat setiap tahunnya, yaitu sebesar: $11312 \mathrm{~kg}$ menjadi 138 $617 \mathrm{~kg}$. Demikian halnya pada tahun 1996 sampai tahun 1997, tahun 1998 sampai tahun 1999 dan tahun 2000 sampai tahun 2001 volume ekspor udang putih Indonesia ke negara Hongkong meningkat sebesar 27867 kg menjadi $77773 \mathrm{~kg} ; 27855 \mathrm{~kg}$ menjadi 1 $312562 \mathrm{~kg}$ dan $248451 \mathrm{~kg}$ menjadi 468 $149 \mathrm{~kg}$.

Kondisi volume ekspor udang putih Indonesia ke negara Hongkong pada tahun 2003 sampai tahun 2007 dan tahun 2008 sampai tahun 2009 meningkat seperti periode sebelumnya meskipun tidak stabil setiap tahun. Berdasarkan data UN Comtrade (2013), peningkatan volume ekspor udang putih Indonesia ke negara Hongkong tahun 2003 sampai tahun 2007, yaitu sebesar: $87432 \mathrm{~kg}$ menjadi $348198 \mathrm{~kg}$ dan peningkatan volume ekspor udang putih Indonesia ke negara Hongkong tahun 
2008 sampai tahun 2009, yaitu sebesar: $330525 \mathrm{~kg}$ menjadi $340956 \mathrm{~kg}$.

Adanya ACFTA (ASEAN-China

Free Trade Area) semenjak peresmian Januari 2010 (Ditjen Kerjasama Perdagangan Internasional 2010) diharapkan mampu memperbesar volume ekspor udang putih Indonesia ke negara Hongkong. Setelah peresmian ACFTA pada awal tahun 2010, volume ekspor udang putih Indonesia ke negara Hongkong semakin menurun karena adanya dampak berkelanjutan yang ditimbulkan dari krisis ekonomi global tahun 2008 terhadap perekonomian negara anggota ASEAN dan Cina.

Pada tahun 2009, besarnya volume ekspor udang putih Indonesia ke negara Hongkong sekitar $340956 \mathrm{~kg}$. Pada tahun 2010, volume ekspor udang putih Indonesia ke negara Hongkong semakin berkurang dari tahun sebelumnya yang mencapai $315499 \mathrm{~kg}$. Demikian halnya pada tahun 2011, tahun 2012 dan tahun 2013, besarnya volume ekspor udang putih Indonesia ke negara Hongkong semakin berkurang yaitu sebesar: 181 $170 \mathrm{~kg} ; 122156 \mathrm{~kg}$ dan $81439 \mathrm{~kg}$ (UN Comtrade, 2013). Jumlah tersebut semakin berkurang setiap tahunnya setelah berlakunya perjanjian ACFTA 2010.

Berlakunya ACFTA tidak dapat meningkatkan volume ekspor udang putih Indonesia ke negara Hongkong. Padahal dalam perjanjian ACFTA menyatakan adanya penghapusan tarif perdagangan antar negara anggota sehingga mengindikasikan ekspor maupun impor antar negara dapat meningkat. Semenjak berlakunya ACFTA tahun 2010, volume ekspor udang putih Indonesia ke negara Hongkong semakin berkurang setiap tahunnya.

Pada tahun 1999, Indonesia mampu mengekspor udang putih ke negara Hongkong mencapai 16 kali total volume ekspor udang putih Indonesia ke negara Hongkong pada tahun 2013 (UN Comtrade 2013). Sebagian besar hasil produksi udang putih Indonesia di ekspor ke negara Hongkong. Kondisi maksimal tersebut tidak mampu dipertahankan Indonesia dalam memenuhi permintaan pasar udang putih dunia khususnya dari negara tujuan (Hongkong) pasca berlakunya perjanjian ACFTA tahun 2010.

Ketidakstabilan volume maupun nilai ekspor udang putih Indonesia ke dunia khususnya negara tujuan (Hongkong) selama periode observasi merupakan sumber permasalahan utama dalam penelitian ini (UN Comtrade 2013). Setelah berlakunya ACFTA tahun 2010 seharusnya volume ekspor udang putih Indonesia ke negara Hongkong yaitu: tahun 2010 sampai tahun 2013 dapat meningkat. Pada faktanya volume ekspor udang putih Indonesia ke negara Hongkong pada tahun 2010 sampai tahun 2013 cenderung menurun.

Terdapat faktor-faktor yang mempengaruhi ketidakstabilan volume ekspor udang putih Indonesia ke negara Hongkong sehingga pada penelitian ini perlu mempelajari faktor-faktor tersebut. Pada akhirnya dapat dirumuskan suatu permasalahan dibagian utama dalam penelitian ini.

Berlakunya ACFTA (ASEANChina Free Trade Area) tahun 2010 serta kebijakan Kementerian Kelautan dan Perikanan mengenai peningkatan jaringan sarana dan prasarana yang termuat dalam UU No. 17 Tahun 2008 dan peningkatan pemanfaatan keekonomian Bioresources yang terdapat dalam Keputusan Presiden No. 78 tahun 2005 menunjukkan terjadinya kecenderungan volume ekspor udang putih Indonesia yang menurun ke negara Hongkong. Padahal dengan kebijakan tersebut seharusnya Indonesia 
dapat meningkatkan volume ekspor udang putih ke negara Hongkong.

Adanya kecenderungan penurunan volume ekspor udang putih Indonesia ke negara Hongkong setelah puncak tertinggi volume ekspor tersebut pada tahun 1999 menunjukkan bahwa keadaan ekspor udang putih Indonesia ke negara Hongkong tidak stabil. Faktor-faktor ekonomi yang berpengaruh terhadap volume ekspor udang putih Indonesia ke negara Hongkong akan dipelajari dengan bahasan yang disesuaikan dengan teori serta penelitian terdahulu.

\section{Tujuan Penelitian}

Ketidakstabilan volume ekspor udang putih Indonesia ke negara Hongkong pasca berlakunya kesepakatan ACFTA tahun 2010 seiring dengan berlakunya kebijakan Kementerian Kelautan dan Perikanan yang termuat dalam UU No. 17 Tahun 2008 dan Keputusan Presiden No. 78 tahun 2005 dapat dipelajari dengan menganalisis faktor-faktor yang mempengaruhinya. Pada akhirnya dirumuskan strategi kebijakan terhadap peningkatan volume ekspor udang putih Indonesia ke negara Hongkong sehingga berimplikasi terhadap peningkatan kontribusi sub sektor perikanan pada PDB sektor pertanian di masa mendatang.

Pentingnya kebijakan yang dapat meningkatkan volume ekspor udang putih Indonesia ke negara Hongkong melalui pengurangan pembiasan ekspor udang putih Indonesia antara ke negara tujuan Hongkong dengan negara tujuan lainnya (Jepang, Malaysia, Singapura dan negara bagian Asia lainnya). Hal tersebut dapat dicapai dengan proporsi volume ekspor yang tepat dan akurat setiap tahun ke negara tujuan ekspor. Dasar kebijakan tersebut merupakan kesempatan dalam meningkatkan volume ekspor udang putih Indonesia ke negara Hongkong.

Pemanfaatan lahan budi daya udang putih Indonesia yang dilakukan secara optimal dapat meningkatkan produksi udang putih dalam negeri sehingga memenuhi permintaan ekspor udang putih dari negara Hongkong. Peran pemerintah yang sangat penting dalam mengatur sistem pasar, menjaga kestabilan harga udang putih Indonesia, menyediakan bantuan kepada nelayan udang putih serta memotivasi nelayan untuk melakukan diversifikasi produk dapat berdampak terhadap meningkatnya volume ekspor udang putih Indonesia.

Beberapa penjelasan singkat diatas merupakan tolak ukur untuk menjawab permasalahan yang terdapat dalam penelitian ini. Adapun penelitian ini bertujuan:

a. Menganalisis faktor-faktor yang mempengaruhi volume ekspor udang putih (Penaeus indicus) Indonesia ke negara Hongkong.

b. Merumuskan kebijakan yang dapat meningkatkan volume ekspor udang putih Indonesia ke negara Hongkong.

\section{Penelitian Terdahulu}

Oktariza (2000), dalam tesisnya yang berjudul Analisis Ekonomi Perkembangan Pasar Ekspor-Impor Udang Antar 4 Negara ASEAN, menganalisis kedudukan udang Indonesia di pasar ASEAN. Secara khusus juga membahas 3 negara lainnya yang menjadi pesaing utama negara Indonesia dalam perdagangan udang ASEAN yaitu: Thailand, Malaysia dan Singapura. Metode dalam penelitian ini menggunakan data time series dari tahun 1977 sampai 1996.

Peubah ekspor udang Indonesia lebih responsif terhadap harga udang dunia dibandingkan dengan harga udang 
di pasar ASEAN. Penawaran ekspor udang Indonesia ke pasar ASEAN dipengaruhi secara nyata oleh peubah harga udang Indonesia di pasar ASEAN, harga udang Indonesia di pasar dunia, ekspor udang tahun sebelumnya dan nilai tukar rupiah dengan dolar Amerika serikat.

Harga udang Indonesia di pasar ASEAN sangat nyata dipengaruhi oleh harga udang dunia, harga udang Indonesia di pasar dunia dan harga udang Indonesia di pasar ASEAN tahun sebelumnya. Nilai elastisitas jangka pendek rata-rata pangsa pasar Indonesia terhadap perubahan harga sebesar 0,52 dan dalam jangka panjang sebesar 0,60 , berarti di pasar ASEAN tingkat persaingan antara ekspor udang Indonesia dengan ekspor ketiga negara lainnya (Thailand, Malaysia dan Singapura) rendah.

Menurut penulis, penelitian mengenai udang perlu ditindak lanjuti. Hal ini guna mengetahui perkembangan komoditas udang khususnya mengenai udang putih Indonesia ke negara Hongkong dan perkembangannya di pasar dunia. Penelitian mengenai udang putih Indonesia belum spesifik serta pembahasan faktor-faktor yang mempengaruhi volume ekspor udang putih juga belum memadai. Maka dari itu, penulis akan meneruskan penelitian tersebut dengan melengkapi bahasan yang lebih khusus mengenai udang putih atau Penaeus indicus Indonesia selama periode 24 tahun terakhir (tahun 1990 sampai tahun 2013) ke negara Hongkong.

\section{METODE PENELITIAN}

\section{Jenis dan Sumber Data}

Penelitian ini menggunakan data sekunder meliputi data kuantitatif tahunan rentang waktu tahun 1990 sampai tahun 2013. Negara tujuan yang dimaksud ialah Hongkong yang dipilih berdasarkan tingkat konsumsinya yang tinggi, nilai ekspor udang putih Indonesia ke negara Hongkong, kerutinan ekspor Indonesia ke negara tersebut setiap tahunnya serta terkait perjanjian kerjasama antara Indonesia dengan Cina dalam ACFTA pada Januari 2010.

Penelitian ini menggunakan data deret waktu atau time series. Volume ekspor udang putih Indonesia ke negara Hongkong merupakan variabel dependen dalam model penelitian, sedangkan variabel bebas atau variabel independen terdiri dari: total populasi negara Hongkong, GDP per kapita riil (tahun dasar 2005) negara Hongkong, harga jual nominal udang putih Indonesia ke negara Hongkong, harga jual nominal udang putih negara pesaing ke negara Hongkong, nilai tukar nominal negara Indonesia terhadap negara Hongkong dan krisis ekonomi Indonesia tahun 1998 sebagai variabel dummy.

Tabel 2 Variabel dalam model

\begin{tabular}{lc}
\hline \multicolumn{1}{c}{ Variabel } & Sumber \\
\hline Volume ekspor udang putih Indonesia & UN Comtrade \\
Harga jual nominal udang putih Indonesia & (www.comtrade.un.org) \\
$\begin{array}{l}\text { Harga jual nominal udang putih negara pesaing } \\
\text { Total populasi negara Hongkong }\end{array}$ & World Bank Group \\
$\begin{array}{l}\text { GDP per kapita riil (tahun dasar 2005) Hongkong } \\
\text { Kurs nominal negara Indonesia terhadap Hongkong }\end{array}$ & (www.worldbank.org) \\
\hline Sumber: UN Comtrade dan World Bank Group &
\end{tabular}




\section{Metode Analisis Data dan Pengolahan Data}

Penelitian ini menggunakan analisis secara kuantitatif dengan analisis ekonometrika. Adapun analisis yang digunakan dalam penelitian ini ialah metode Ordinary Least Square (OLS) guna menganalisis faktor-faktor yang mempengaruhi volume ekspor udang putih Indonesia ke negara Hongkong. Metode deskriptif pada penelitian ini dianalisis berdasarkan studi pustaka. Pengolahan data yang dilakukan menggunakan bantuan software Microsoft excel 2007 dan software minitab 15.

Menurut Juanda (2009), prinsip dasar metode (jumlah) kuadrat (sisaan) terkecil atau yang dikenal dengan metode OLS (Ordinary Least Square) ialah meminimumkan jumlah kuadrat simpangan antara data aktual dengan data dugaannya. Salah satu fungsi metode OLS ialah untuk menduga parameter $\alpha$ dan $\beta$ atau parameter regresi.

Suatu statistik dikatakan sebagai penduga parameter yang konsisten apabila ada peluang untuk memperoleh perbedaan statistik dan parameter yang semakin mendekati nol apabila jumlah individu sampel bertambah banyak. Pendugaan nilai koefisien regresi dengan metode kuadrat terkecil ditujukan untuk mencapai kondisi statistik yang baik dengan meminimumkan selisih kuadrat antara Y-observasi dan Y-dugaan.

\section{Model Penelitian}

Pada penelitian ini model yang digunakan mengacu pada fungsi regresi. Secara umum, fungsi regresi dapat dituliskan sebagai berikut.

$$
\mathrm{Y}=\mathrm{a}_{0}+\sum_{\mathrm{i}=1}^{\mathrm{n}} \mathrm{a}_{\mathrm{i}} \mathrm{x}_{\mathrm{i}}+\mathrm{e}_{\mathrm{i}}
$$

Keterangan:

$$
\begin{aligned}
\mathrm{Y}= & \text { Peubah tak bebas } \\
\mathrm{a}_{0}= & \text { Intersep } \\
\mathrm{a}_{\mathrm{i}}= & \text { Koefisien variabel independen } \\
\mathrm{x}_{\mathrm{i}}= & \text { Peubah bebas yang menjelaskan } \\
& \text { peubah tak bebas atau } \mathrm{Y} \\
\mathrm{e}_{\mathrm{i}}= & \text { Error term atau pengaruh sisa } \\
\mathrm{i}= & 1,2,3, \ldots, \mathrm{n} \text { banyaknya peubah } \\
& \text { bebas dalam fungsi }
\end{aligned}
$$

Terdapat selisih nilai yang cukup besar pada variabel dalam model penelitian antara lain: variabel volume ekspor udang putih Indonesia ke negara Hongkong, total populasi negara Hongkong, GDP per kapita riil (tahun dasar 2005) negara Hongkong, harga jual nominal udang putih Indonesia ke negara Hongkong, harga jual nominal udang putih negara pesaing ke negara Hongkong dan kurs nominal negara Indonesia terhadap negara Hongkong sehingga perlu ditransformasi ke model logaritma dengan memberikan ln pada setiap data. Pemilihan dilakukan karena terdapat ketimpangan nilai yang besar antar variabel yang digunakan, baik variabel independen maupun variabel dependen.

Setelah dirumuskan, maka didapatkan suatu model penelitian dengan melakukan transformasi setiap variabel dengan logaritma agar mendapatkan nilai korelasi yang lebih baik dan untuk mengatasi masalah selisih nilai pada variabel yang cukup besar. Adapun model persamaan regresi untuk menduga volume ekspor udang putih Indonesia ke negara Hongkong ialah sebagai berikut.

$$
\begin{aligned}
\operatorname{Ln} Y_{t}=\alpha_{t} & +\beta_{1} \operatorname{Ln} \mathrm{TP}_{t}+\beta_{2} \operatorname{Ln} \mathrm{GDP}_{\mathrm{t}} \\
& -\beta_{3} \mathrm{Ln} \mathrm{HJ}_{\mathrm{t}}+\beta_{4} \operatorname{Ln} \mathrm{HJ}_{\mathrm{psg}} \\
& +\beta_{5} \operatorname{Ln~NTN}_{\mathrm{t}}+\beta_{5} \mathrm{D}_{\mathrm{t}}+\mathrm{e}_{\mathrm{t}}
\end{aligned}
$$

Keterangan:

$$
\begin{aligned}
\operatorname{Ln~} Y_{t}= & \text { Logaritma natural } \\
& \text { volume ekspor udang } \\
& \text { putih Indonesia }(\mathrm{kg})
\end{aligned}
$$




$$
\begin{aligned}
& \operatorname{Ln} \mathrm{TP}_{\mathrm{t}}=\text { Logaritma natural total } \\
& \text { populasi negara } \\
& \text { Hongkong (orang) } \\
& \text { Ln GDP } \mathrm{t}_{\mathrm{t}}=\text { Logaritma natural GDP } \\
& \text { per kapita riil (tahun } \\
& \text { dasar 2005) negara } \\
& \text { Hongkong (US\$) } \\
& \text { Ln } \mathrm{HJ}_{\mathrm{t}} \quad=\text { Logaritma natural harga }
\end{aligned}
$$

\section{Pengujian Statistika Analisis Regresi Koefisien Determinasi $\left(\mathbf{R}^{\mathbf{2}}\right)$}

Koefisien determinasi adalah suatu angka yang mengukur keragaman pada variabel dependen dan diperjelas oleh variasi pada model regresi. Kisaran nilainya antara nol sampai satu $\left(0<\mathrm{R}^{2}<1\right)$, artinya jika nilai semakin mendekati angka 1 maka model yang terbentuk mampu menjelaskan keragaman dari variabel dependen tersebut. Demikian pula sebaliknya, jika nilai semakin mendekati angka 0 maka model yang terbentuk tidak mampu menjelaskan keragaman dari variabel dependen. Beberapa jenis uji hipotesis yang dapat dilakukan terhadap variabel regresi, yaitu sebagai berikut.

\section{1) Uji F-statistic}

Untuk mengetahui pengaruh semua variabel independen didalam model secara berbeda nyata terhadap variabel dependen, maka perlunya uji $\mathrm{F}$ dengan perbandingan nilai kritis $\mathrm{f}$ dengan hasil f-hitung. Adapun kriteria ujinya adalah: $F_{\text {hitung }}>F_{\text {tabel, }(\mathrm{k}-1)(\mathrm{n}-\mathrm{k})}$ atau nilai probability yang dimiliki $<\alpha$ maka tolak $\mathrm{H}_{0}$, demikian sebaliknya. Jika tolak $\mathrm{H}_{0}$ berarti secara bersama-sama variabel bebas dalam model berpengaruh nyata terhadap variabel tidak bebas pada taraf nyata $\alpha \%$, demikian pula sebaliknya.

\section{2) Uji T-statistic}

Pengujian ini dilakukan untuk mengetahui pengaruh berbeda nyata atau tidaknya variabel independen secara individu (masing-masing) terhadap variabel dependen. Jika nilai $t_{\text {hitung }}>\mathrm{t}_{\text {tabel, }(\mathrm{k}-1)(\mathrm{n}-\mathrm{k})}$ atau nilai probabilitas (p-value) lebih kecil dari taraf nyata maka tolak $\mathrm{H}_{0}$, demikian sebaliknya. Jika tolak $\mathrm{H}_{0}$ berarti variabel bebas dalam model berpengaruh nyata terhadap variabel tidak bebas pada taraf nyata $\alpha \%$, demikian sebaliknya.

\section{Pengujian Asumsi Klasik}

\section{1) Uji Normalitas}

Uji normalitas digunakan untuk memeriksa apakah error term menyebar normal atau tidak. Hipotesis yang digunakan adalah:

$\mathrm{H}_{0}$ : error term menyebar normal

$\mathrm{H}_{1}$ : error term tidak menyebar normal

Uji normalitas diaplikasikan dengan melakukan tes Kolmogorov Smirnov, jika nilai probabilitas yang diperoleh lebih besar dari taraf nyata yang digunakan, maka tidak tolak $\mathrm{H}_{0}$ yang berarti error term dalam model 
sudah menyebar normal (Gujarati 2006).

\section{2) Uji Heteroskedastisitas}

Heteroskedastisitas adalah salah satu penyimpangan pada asumsi klasik statistika. Suatu fungsi dikatakan baik apabila memenuhi asumsi homoskedastisitas (tidak terdapat heteroskedastisitas) atau memiliki ragam error yang sama. Salah satu cara mendeteksi heteroskedastisitas adalah dengan menggunakan uji Gletser. Uji Gletser menggunakan residual kuadrat sebagai variabel dependen yang diregresikan terhadap variabel-variabel independennya. Adapun hipotesis uji Gletser ialah sebagai berikut.

$\mathrm{H}_{0}$ : Homoskedastisitas

$\mathrm{H}_{1}$ : Heteroskedastisitas
Apabila nilai p-value lebih kecil dari taraf nyata $(\alpha)$ yang digunakan maka tolak $\mathrm{H}_{0}$ sehingga terjadi pelanggaran asumsi heteroskedastisitas, demikian sebaliknya. Salah satu cara mengatasi masalah ini adalah dengan menggunakan metode Generalized Least Square (GLS). Metode ini merupakan metode kuadrat terkecil yang terboboti, yaitu model ditransformasi dengan memberikan bobot pada data asli (Juanda 2009).

\section{3) Uji Autokorelasi}

Autokorelasi adalah adanya korelasi serial antara sisaan $\left(\mu_{\mathrm{t}}\right)$. Untuk mengetahui ada tidaknya autokorelasi dapat dilakukan uji Durbin-Watson (DW) seperti yang terdapat pada Tabel berikut.

Tabel 3 Selang nilai statistik Durbin-Watson dan kesimpulannya

\begin{tabular}{ll}
\hline Nilai Durbin-Watson & Kesimpulan \\
\hline $0<\mathrm{DW}<\mathrm{DL}$ & Ada autokorelasi positif \\
$\mathrm{DL}<\mathrm{DW}<\mathrm{DU}$ & Tidak ada kesimpulan \\
$\mathrm{DU}<\mathrm{DW}<4-\mathrm{DU}$ & Tidak ada autokorelasi \\
$4-\mathrm{DU}<\mathrm{DW}<4-\mathrm{DL}$ & Tidak ada kesimpulan \\
$4-\mathrm{DL}<\mathrm{DW}<4$ & Ada autokorelasi negatif \\
\hline
\end{tabular}

Apabila nilai Durbin-Watson lebih dari 1.5 dan mendekati 2, dapat dikatakan tidak terdapat autokorelasi dalam model, demikian sebaliknya. Salah satu cara untuk mengatasi masalah ini adalah dengan menggunakan metode Generalized Least Square dalam estimasi model (Gujarati, 2006).

\section{4) Uji Multikolinearitas}

Multikolinearitas merupakan suatu penyimpangan asumsi akibat adanya keterkaitan atau hubungan linier antar variabel bebas penyusun model. Berdasarkan Juanda (2009), indikasi adanya multikolinearitas atau kolinearitas ganda dapat dilihat dari uji $F$ yang menyimpulkan minimal ada peubah bebas memiliki pengaruh nyata dalam model atau memiliki nilai Rsquare yang tinggi, tetapi dalam uji $\mathrm{T}$ tidak terdapat koefisien yang berbeda nyata karena simpangan baku koefisiennya besar.

\section{HASIL DAN PEMBAHASAN}

\section{Kondisi dan Kecenderungan Volume Ekspor Udang Putih Indonesia}

Selama periode observasi (tahun 1990 sampai tahun 2013), kecenderungan volume ekspor udang putih Indonesia ke dunia dan beberapa negara tidak stabil. Pada tahun 1999, volume ekspor udang putih Indonesia ke dunia sangat tinggi dari tahun sebelum dan 
sesudahnya. Tahun 1999 merupakan puncak tertinggi volume ekspor udang putih Indonesia ke dunia maupun ke negara-negara tujuan ekspor lainnya, seperti yang terlihat pada Gambar 5. Kemudian terjadi penurunan volume ekspor udang putih Indonesia ke dunia setelah tahun 1999.

Dalam Gambar 5, volume ekspor udang putih Indonesia cenderung lebih banyak ke negara Hongkong, kemudian diikuti oleh negara lainnya, seperti: Jepang, Malaysia, Singapura dan bagian negara Asia lainnya. Pada tahun 1999, volume ekspor udang putih Indonesia ke dunia sebanyak $2408041 \mathrm{~kg}$. Pada saat pencapaian puncak tertinggi tersebut, ekspor Indonesia ke negara Hongkong hanya mencapai $1312562 \mathrm{~kg}$ (UN Comtrade 2013). Jumlah ini merupakan $1 / 2$ dari total volume ekspor udang putih Indonesia ke dunia.

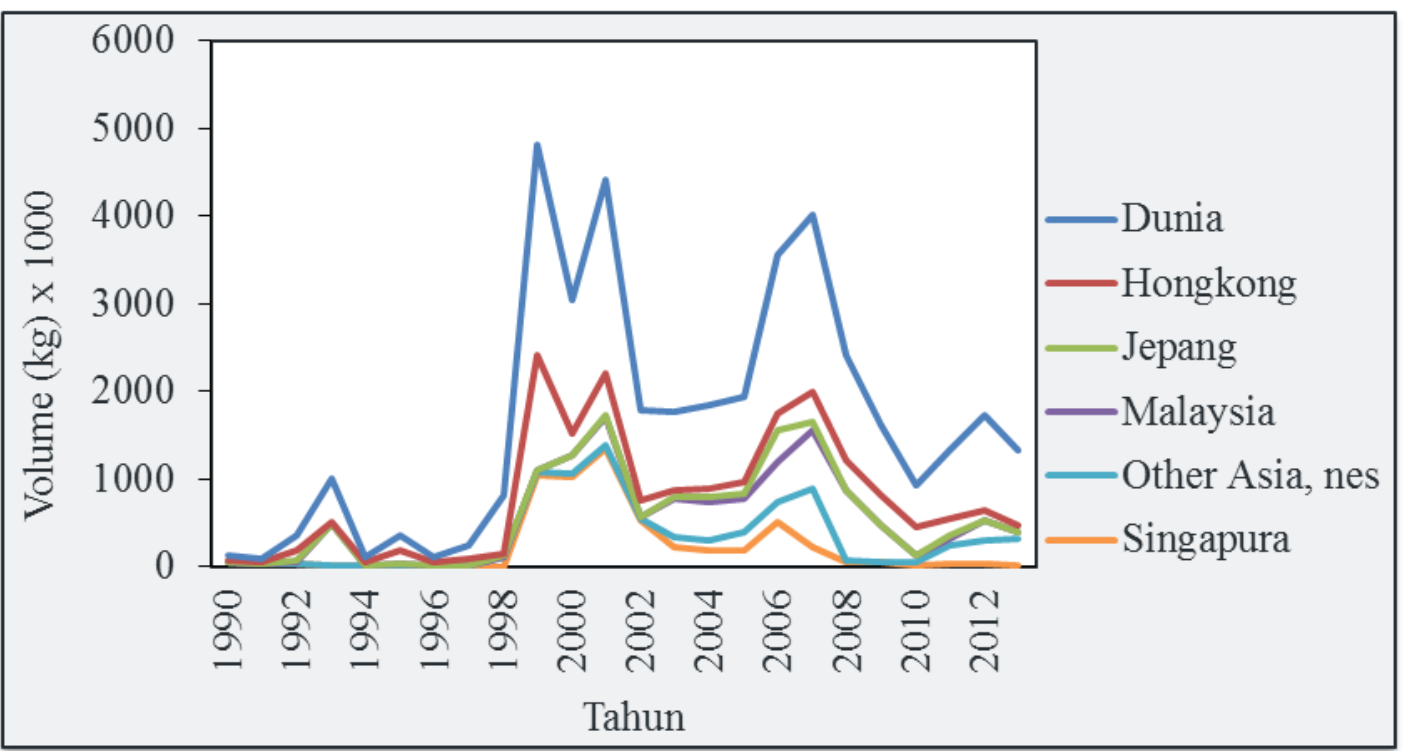

Sumber: UN Comtrade 2013 (diolah)

Gambar 5 Volume ekspor ke dunia dan beberapa negara

Terjadinya penurunan volume ekspor udang putih Indonesia ke dunia setelah tahun 1999 juga diikuti dengan penurunan volume ekspor udang putih Indonesia ke negara Hongkong. Berbeda dengan negara tujuan ekspor lainnya, yaitu Malaysia yang cenderung mengalami peningkatan setelah tahun tersebut. Pada tahun 1999, volume ekspor udang putih Indonesia ke negara Malaysia sebesar $4875 \mathrm{~kg}$. Setelah tahun 1999, volume ekspor udang putih Indonesia ke negara Malaysia pada tahun 2000 meningkat menjadi sebesar $207506 \mathrm{~kg}$ (UN Comtrade 2013). Demikian halnya dengan negara tujuan ekspor lainnya, seperti: negara Jepang, negara Singapura dan bagian negara Asia lainnya yang ikut mengalami penurunan volume ekspor udang putih Indonesia sama seperti negara Hongkong saat volume ekspor udang putih Indonesia ke dunia menurun pasca tahun 1999.

Titik terendah volume ekspor udang putih Indonesia ke dunia terjadi pada tahun 1991 dengan jumlah 49143 $\mathrm{kg}$ sedangkan volume ekspor udang putih Indonesia ke negara Hongkong pada tahun 1991 sebesar $15750 \mathrm{~kg}$. Berdasarkan data yang dimuat pada $U N$ Comtrade (2013), jumlah volume ekspor udang putih Indonesia ke negara Hongkong lebih kecil dibandingkan 
jumlah volume ekspor udang putih Indonesia ke dunia selama periode observasi. Hal ini karena jumlah volume ekspor udang putih Indonesia ke dunia merupakan total dari keseluruhan jumlah ekspor udang putih Indonesia ke berbagai negara.

Meskipun jumlah volume ekspor udang putih Indonesia ke negara Hongkong lebih kecil dari jumlah volume ekspor udang putih Indonesia ke dunia selama periode observasi, dengan berlakunya perjanjian ACFTA (2010) seharusnya volume ekspor udang putih Indonesia ke negara Hongkong dapat meningkat setelah tahun tersebut. Kenyataannya, setelah tahun 2010 volume ekspor udang putih Indonesia ke negara Hongkong mengalami penurunan yang cukup curam.

Berlakunya ACFTA semenjak tahun 2010, tidak meningkatkan volume ekspor udang putih Indonesia ke negara anggota ASEAN lainnya maupun ke Cina. Volume ekspor udang putih Indonesia ke negara Malaysia pada tahun 2010 maupun tahun 2011 mencapai $78960 \mathrm{~kg}$ dan $69972 \mathrm{~kg}$. Pada tahun 2009 (periode sebelum berlakunya ACFTA), volume ekspor udang putih Indonesia ke negara Malaysia sebesar 411748 kg. Jumlah tersebut merupakan $2 \mathrm{x}$ total volume ekspor udang putih Indonesia ke negara Malaysia pada tahun berlakunya perjanjian ACFTA yaitu tahun 2010 (UN Comtrade 2013).

\section{Pangsa Pasar Udang Putih Indonesia Terhadap Total Impor Hongkong}

Penawaran udang putih Indonesia lebih besar dibandingkan permintaan ekspor dari negara Hongkong yang dilihat dari besarnya selisih antara volume ekspor udang putih Indonesia ke negara Hongkong dengan besarnya volume impor negara Hongkong dari negara Indonesia. Menurunnya kualitas udang putih Indonesia saat tiba di pelabuhan atau distributor induk negara Hongkong merupakan penyebab selisih tersebut sehingga permintaan negara Hongkong terhadap udang putih Indonesia lebih kecil dari jumlah ekspor yang ditawar oleh negara Indonesia.

Meskipun negara Indonesia tengah berupaya meningkatkan kualitas produk dan jumlah penawaran udang putih ke negara Hongkong, pangsa pasar udang putih Indonesia masih relatif kecil yaitu berada di bawah 50\% setiap tahunnya. Pada tahun 1998, pangsa pasar udang putih Indonesia di negara Hongkong mencapai 34,19\% (UN Comtrade 2013). Persentase pangsa pasar tersebut lebih tinggi dibandingkan tahun lainnya seperti pada Gambar 6, karena negara Indonesia tengah mengalami krisis ekonomi yang menyebabkan nilai tukar rupiah terhadap dolar terdepresiasi sehingga harga-harga di negara Indonesia lebih murah dibandingkan negara Hongkong. Lemahnya nilai tukar rupiah terhadap dolar Hongkong (depresiasi) merupakan penyebab volume ekspor udang putih Indonesia ke negara Hongkong meningkat pada tahun tersebut. 


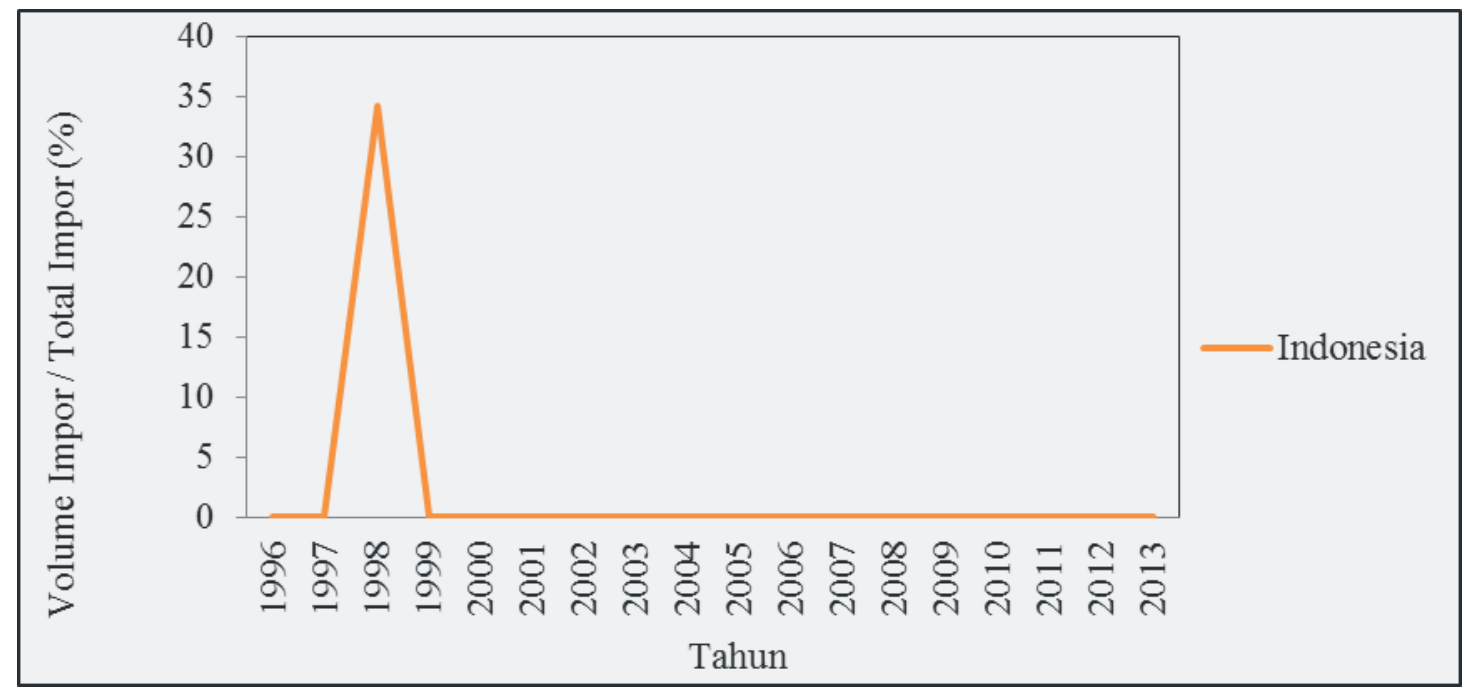

Sumber: UN Comtrade 2013 (diolah)

Gambar 6 Tren pangsa pasar udang putih Indonesia di negara Hongkong

Berdasarkan UN Comtrade (2013), setelah tahun 1998 pangsa pasar udang putih Indonesia menurun dengan kisaran 0,001\%-0,016\%. Menurunnya pangsa pasar udang putih Indonesia merupakan indikasi adanya penawaran ekspor negara pesaing dan negaranegara penghasil udang lainnya yang semakin banyak masuk ke negara Hongkong.

\section{Validitas Model Persamaan Regresi}

Hasil estimasi model adalah sebagai berikut:

$$
\begin{aligned}
& \operatorname{LnY}_{\mathrm{t}}=-153+14,0 \mathrm{Ln} \mathrm{TP}_{\mathrm{t}} \\
&-2,95 \mathrm{Ln} \mathrm{GDP}_{\mathrm{t}} \\
&-1,38 \mathrm{Ln} \mathrm{HJ} \\
&-0,298 \mathrm{Ln} \mathrm{HJ} \mathrm{psg}_{\mathrm{t}} \\
&-3,87 \mathrm{Ln}_{\mathrm{NTN}_{\mathrm{t}}}+5,08 \mathrm{D}_{\mathrm{t}}
\end{aligned}
$$

Sebelum membahas hasil estimasi model, maka dilakukan uji validitas model sebagai berikut.

\section{1) Uji Normalitas}

Dari hasil uji kenormalan dengan Kolmogorov Smirnov, diperoleh nilai probability lebih besar dari 0,150 . Hal ini mengindikasikan bahwa nilai probability $>\alpha 10 \%$ maka keputusan yang dapat diambil ialah tidak tolak $\mathrm{H}_{0}$. Residual atau error term model volume ekspor udang putih Indonesia ke negara Hongkong menyebar dengan normal sehingga asumsi kenormalan sudah terpenuhi (Lampiran 2).

\section{2) Uji Heteroskedastisitas}

Apabila nilai p-value lebih kecil dari taraf nyata $(\alpha)$ yang digunakan maka tolak $\mathrm{H}_{0}$ sehingga terjadi pelanggaran asumsi heteroskedastisitas, demikian sebaliknya. Pada hasil analisis menggunakan uji Gletser, nilai probability yang diperoleh lebih besar dari taraf nyata $5 \%$, yaitu sebesar 0,445 . Hal ini mengindikasikan bahwa model volume ekspor udang putih Indonesia ke negara Hongkong tidak terdapat masalah heteroskedastisitas yang berarti asumsi homoskedastisitas pada model sudah terpenuhi (Lampiran 3).

\section{3) Uji Autokorelasi}

Berdasarkan hasil yang diperoleh, nilai Durbin-Watson statistic mencapai 2,04762. Adapun jumlah variabel independen $(\mathrm{k})$ ialah 6 sedangkan jumlah sampel (n) sebanyak 24, maka 
dalam hal ini $\mathrm{d}_{\mathrm{L}}=0,652$ dan $\mathrm{d}_{\mathrm{U}}=1,797$. Nilai $4-\mathrm{d}_{\mathrm{L}}=3,348$ sedangkan nilai $4-\mathrm{d}_{\mathrm{U}}=$ 2,203. Nilai tersebut menunjukkan bahwa Durbin-Watson statistic berada diantara wilayah yang tidak terdapat autokorelasi, karena nilai DurbinWatson statistic berada pada wilayah $\mathrm{D}_{\mathrm{U}}<\mathrm{DW}<4-\mathrm{D}_{\mathrm{U}}$. Nilai Durbin-Watson statistic menunjukkan nilai yang lebih besar dari 1,5 dan mendekati 2 sehingga dalam model volume ekspor udang putih Indonesia ke negara Hongkong tidak terdapat autokorelasi.

\section{4) Uji Multikolinearitas}

Dari hasil analisis yang dilakukan, dalam model tidak terdapat masalah multikolinearitas. Nilai probabilitas pada uji $\mathrm{F}$ sebesar 0,000 atau lebih kecil dari taraf nyata $10 \%$ sehingga disimpulkan bahwa minimal ada peubah bebas memiliki pengaruh yang sangat nyata dalam model. Selain itu, nilai Rsquare yang dimiliki sangat besar mencapai 96,7\% sedangkan dalam uji T semua koefisien regresi terbukti berbeda nyata dengan taraf nyata $10 \%$. Kesimpulannya adalah dalam model volume ekspor udang putih Indonesia ke negara Hongkong tidak terdapat multikolinearitas.

Berdasarkan uji asumsi klasik terhadap model persamaan regresi tersebut, tidak terdapat pelanggaran pada masing-masing uji. Dalam hal ini, model volume ekspor udang putih Indonesia ke negara Hongkong sudah valid.

\section{Identifikasi Faktor-Faktor yang Mempengaruhi Volume Ekspor}

Setelah dilakukan regresi data dengan metode Least Squares, diperoleh hasil estimasi sebagai berikut: terdapat tiga variabel independen yang tidak sesuai dengan hipotesis penelitian atau teori dilihat dari nilai koefisien yang dimiliki. Adapun variabel yang dimaksud yaitu: variabel GDP per kapita riil (tahun dasar 2005) negara Hongkong, harga jual nominal udang putih negara pesaing ke negara Hongkong dan nilai tukar nominal negara Indonesia terhadap negara Hongkong. Berdasarkan hasil estimasi, tiga variabel independen lainnya memiliki kesesuaian dengan hipotesis penelitian. Adapun variabel yang dimaksud ialah: total populasi negara Hongkong, harga jual nominal udang putih Indonesia ke negara Hongkong dan krisis ekonomi Indonesia tahun 1998 yang menjadi variabel dummy.

Dengan taraf nyata sebesar $10 \%$, semua variabel independen pada model estimasi memiliki pengaruh yang berbeda nyata terhadap volume ekspor udang putih Indonesia. Variabel yang dimaksud ialah: total populasi negara Hongkong, GDP per kapita riil (tahun dasar 2005) negara Hongkong, harga jual nominal udang putih Indonesia ke negara Hongkong, harga jual nominal udang putih negara pesaing ke negara Hongkong, nilai tukar nominal negara Indonesia terhadap negara Hongkong dan dummy krisis ekonomi Indonesia tahun 1998. Hasil analisis regresi dengan model volume ekspor udang putih Indonesia ke negara Hongkong seperti pada Tabel 4. 
Tabel 4 Hasil estimasi koefisien regresi model

\begin{tabular}{lrr}
\hline \multicolumn{1}{c}{ Variabel } & Koefisien & Probabilitas \\
\hline Konstanta & $-153,10$ & $\left.0,099^{*}\right)$ \\
Populasi & 13,995 & $\left.0,054^{*}\right)$ \\
GDP per kapita riil & $-2,947$ & $\left.0,014^{*}\right)$ \\
Harga jual Indonesia (harga ekspor) & $-1,3828$ & $\left.0,000^{*}\right)$ \\
Harga jual negara pesaing & $-0,2977$ & $\left.0,059^{*}\right)$ \\
Kurs nominal & $-3,871$ & $\left.0,064^{*}\right)$ \\
Dummy krisis ekonomi (1998) & 5,080 & $\left.0,032^{*}\right)$ \\
\hline
\end{tabular}

*) berbeda nyata pada taraf nyata $10 \%$

Berdasarkan hasil yang diperoleh pada Tabel 4, disimpulkan bahwa variabel independen yang terdiri dari: total populasi negara Hongkong, GDP per kapita riil (tahun dasar 2005) negara Hongkong, harga jual nominal udang putih Indonesia ke negara Hongkong, harga jual nominal udang putih negara pesaing ke negara Hongkong, nilai tukar nominal negara Indonesia terhadap negara Hongkong serta variabel dummy yaitu krisis ekonomi negara Indonesia tahun 1998 pada model terpilih secara berbeda nyata mempengaruhi volume ekspor udang putih Indonesia ke negara Hongkong pada taraf nyata $10 \%$. Masing-masing variabel independen tersebut dapat dijelaskan pada uraian di bawah ini.

\section{1) Total Populasi Negara Hongkong}

Menurut Yuniarti (2007)

menyatakan bahwa pertumbuhan penduduk di negara tujuan ekspor berimplikasi pada peningkatan permintaan terhadap barang dan jasa, sehingga kurva permintaan bergeser ke kanan dan menyebabkan terjadinya excess demand pasar internasional dengan asumsi permintaan tetap, cateris paribus. Hal ini mengindikasikan bahwa populasi berpengaruh positif terhadap aliran perdagangan ekspor.

Berdasarkan hasil hipotesis penelitian, total populasi negara Hongkong berpengaruh positif terhadap volume ekspor udang putih Indonesia ke negara Hongkong. Nilai koefisien variabel total populasi negara Hongkong pada hasil estimasi sebesar 13,995 yang menunjukkan bahwa total populasi negara Hongkong berpengaruh positif terhadap volume ekspor udang putih Indonesia. Hal ini mengindikasikan bahwa nilai koefisien variabel total populasi negara Hongkong sesuai dengan hipotesis penelitian. Koefisien tersebut sekaligus dapat menunjukkan nilai elastisitas dari variabel total populasi negara Hongkong.

Berdasarkan hasil estimasi model, nilai koefisien yang dimiliki variabel total populasi negara Hongkong sebesar 13,995 dapat diartikan bahwa peningkatan total populasi negara Hongkong sebesar 1\%, maka volume ekspor udang putih Indonesia ke negara Hongkong akan meningkat sebesar 13,995\%, dengan asumsi cateris paribus. Dari hasil uji $\mathrm{T}$ diperoleh $\mathrm{t}$ hitung sebesar 2,07 atau nilai probabilitas sebesar 0,054. Nilai tersebut mengindikasikan bahwa variabel total populasi negara Hongkong memiliki pengaruh yang berbeda nyata terhadap volume ekspor udang putih Indonesia dengan taraf nyata sebesar $10 \%$.

\section{2) GDP Per Kapita Riil (Tahun Dasar 2005) Negara Hongkong} Dalam hipotesis penelitian terdapat pengaruh positif GDP per kapita riil (tahun dasar 2005) negara 
Hongkong terhadap volume ekspor udang putih Indonesia. Berdasarkan pendekatan teori dari Lipsey et al (1995), GDP per kapita riil (tahun dasar 2005) negara Hongkong sebagai variabel independen dalam analisis faktor pengaruh volume ekspor udang putih Indonesia yang dapat menunjukkan besarnya kemampuan perekonomian negara Hongkong untuk meningkatkan permintaan ekspor udang putih dari Indonesia. Semakin besar GDP per kapita riil yang dihasilkan suatu negara semakin besar pula kemampuan negara tersebut untuk melakukan perdagangan.

Berdasarkan hasil estimasi model, nilai koefisien variabel GDP per kapita riil (tahun dasar 2005) negara Hongkong sebesar -2,947. Hal tersebut menunjukkan bahwa GDP per kapita konstan 2005 negara Hongkong berpengaruh negatif terhadap volume ekspor udang putih Indonesia. Nilai tersebut mengindikasikan bahwa nilai koefisien variabel GDP per kapita riil (tahun dasar 2005) negara Hongkong pada hasil estimasi tidak sesuai dengan hipotesis penelitian.

Ketidaksesuaian tersebut disebabkan oleh negara Hongkong tidak hanya mengimpor udang putih dari negara Indonesia saja setiap tahunnya, melainkan dari negara lainnya untuk memenuhi permintaan domestik negara Hongkong. Selain dari negara Indonesia, negara Hongkong juga mengimpor udang putih dari beberapa negara lainnya, seperti: USA, Thailand, Sri Lanka, Filipina, New Zealand, Malaysia, India, Kanada dan Australia (UN Comtrade 2013).

Pada Gambar 7, tahun 1996 sampai tahun 1997 kondisi impor udang putih negara Hongkong dari negara Indonesia mengalami penurunan. Pada tahun yang sama, volume impor negara
Hongkong dari negara Malaysia, New Zealand, Thailand dan USA semakin meningkat.

Berdasarkan UN Comtrade (2013), besarnya permintaan volume ekspor udang putih Indonesia oleh negara Hongkong semakin menurun pada tahun 1998 sampai tahun 2000. Berbeda halnya dengan permintaan volume ekspor udang putih oleh negara Hongkong yang mengalami peningkatan dari negara lainnya, seperti: negara Australia dan New Zealand. Volume impor negara Hongkong dari negara Indonesia semakin menurun pada tahun 2005 sampai tahun 2006 sedangkan permintaan impor udang putih negara Hongkong dari negara lainnya, seperti: negara Australia, India, Malaysia, New Zealand, Sri Lanka, Thailand dan USA semakin meningkat.

Kondisi permintaan ekspor udang putih negara Hongkong dari negara Indonesia semakin menurun dari tahun 2012 sampai tahun 2013. Kondisi tersebut berbeda dengan negara eksportir lainnya yang mengalami peningkatan permintaan ekspor udang putih oleh negara Hongkong, seperti: negara Kanada, India dan Thailand ( $U N$ Comtrade 2013).

Total permintaan ekspor udang putih negara Hongkong dari dunia juga semakin menurun yang terjadi pada tahun 1996 sampai tahun 1997, tahun 2001 sampai tahun 2005, tahun 2006 sampai tahun 2007, tahun 2009 sampai tahun 2011 dan tahun 2012 sampai tahun 2013. Meskipun pada tahun lainnya permintaan total negara Hongkong semakin meningkat, besarnya produksi udang putih negara Indonesia cenderung turun pada beberapa tahun tertentu sehingga tidak mampu memenuhi permintaan ekspor negara Hongkong. 


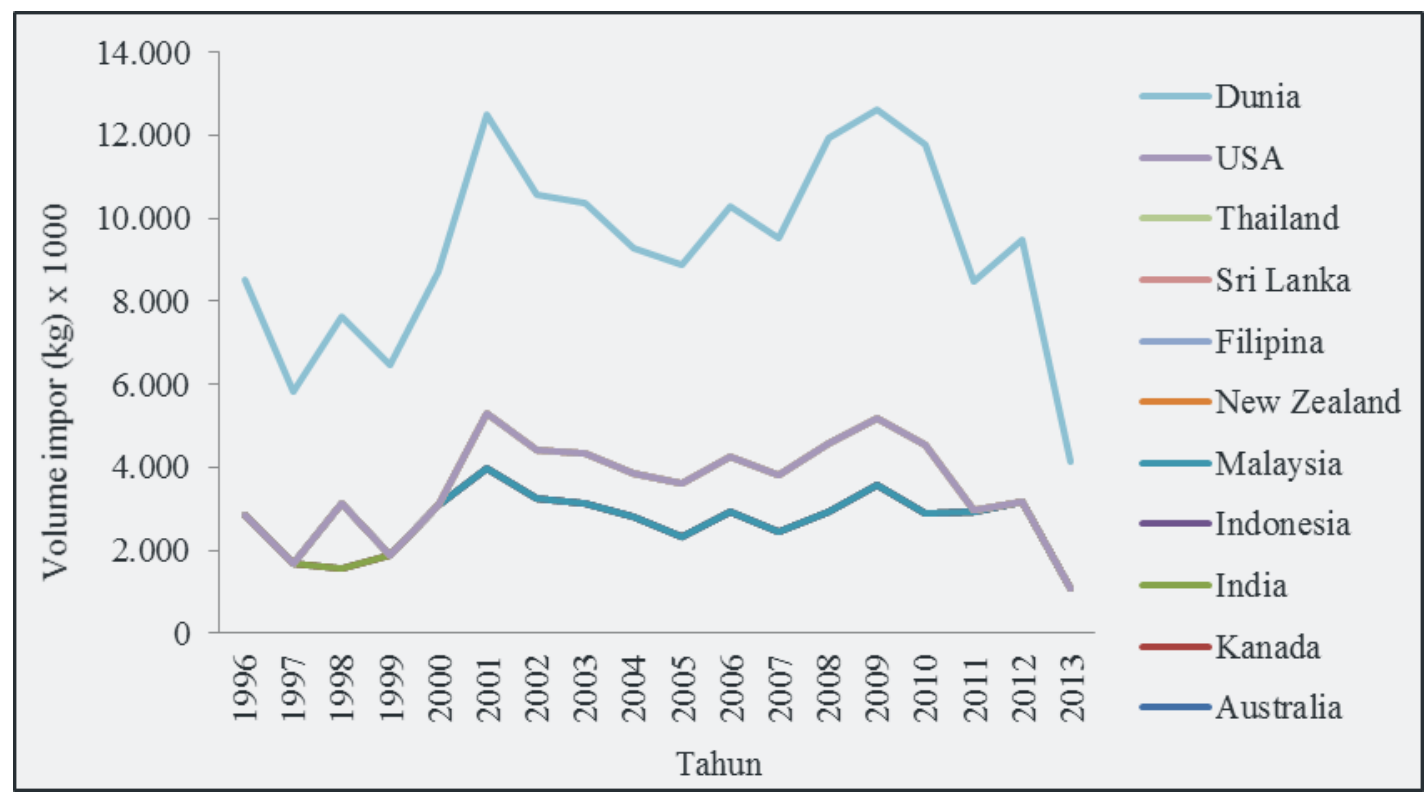

Sumber: UN Comtrade 2013 (diolah)

Gambar 7 Volume impor negara Hongkong dari beberapa Negara

Selain dipengaruhi oleh besarnya permintaan ekspor negara Hongkong dari beberapa negara lainnya (eksportir), ada faktor pengaruh lainnya yang berimplikasi terhadap menurunnya volume ekspor udang putih Indonesia pada saat GDP per kapita riil (tahun dasar 2005) negara Hongkong mengalami peningkatan yaitu: jenis barang yang diekspor ke negara Hongkong bersifat inferior. Terdapat hubungan yang negatif antara kenaikan GDP per kapita riil (tahun dasar 2005) negara Hongkong dengan udang putih yang diekspor oleh negara Indonesia yang bersifat inferior ke negara Hongkong. Bertambahnya GDP per kapita riil (tahun dasar 2005) negara Hongkong akan menurunkan permintaan ekspornya dari negara Indonesia.

Variabel GDP per kapita riil (tahun dasar 2005) negara Hongkong tidak hanya meliputi besarnya ekspor (X) maupun impor (M) negara tersebut, melainkan terdapat komponen lainnya dalam variabel GDP. Berdasarkan Mankiw (2006), komponen GDP terdiri dari: konsumsi (C), investasi (I), pengeluaran pemerintah $(\mathrm{G})$ dan net ekspor (NX). Bertambahnya nilai GDP per kapita riil (tahun dasar 2005) negara Hongkong dapat diperoleh dari besarnya tingkat konsumsi, investasi yang cenderung meningkat diberbagai sektor maupun peningkatan belanja pemerintah negara Hongkong.

Negara Hongkong terus berkembang dengan basis wawasan ekonomi yang lebih berkonsentrasi pada kegiatan yang memiliki nilai tambah yang tinggi dan dilengkapi dengan kerjasama ekonominya dengan Cina daratan (daratan) yang semakin erat. Salah satu bentuk kerjasamanya ialah adanya investasi dalam skala besar pada lintas batas wilayah regionalnya. Selain itu infrastruktur dalam negeri berupa proyek akan terus meningkat guna meningkatkan daya saing ekonomi negara Hongkong (World Trade Organization 2014).

Berdasarkan trade policy review negara Hongkong yang termuat dalam World Trade Organization (2014), lembaga-lembaga dan kebijakan pada negara Hongkong menerapkan aturan hukum, pasar terbuka, sistem pajak 
yang rendah dan sederhana serta keluwesan dalam bidang bisnis merupakan landasan kemakmuran negara Hongkong. Hal tersebut memberikan dampak terhadap peningkatan investasi domestik maupun investasi asing ke negara Hongkong. Pengaruh bertambahnya GDP per kapita riil (tahun dasar 2005) negara Hongkong yang tidak diikuti dengan bertambahnya volume ekspor udang putih Indonesia ke negara tersebut merupakan akibat dari kontribusi investasi maupun belanja pemerintah negara Hongkong yang lebih tinggi terhadap pertumbuhan GDP dibandingkan kontribusi impor negara Hongkong.

Nilai koefisien yang dimiliki variabel GDP per kapita riil (tahun dasar 2005) negara Hongkong sebesar $-2,947$ dapat diartikan bahwa peningkatan GDP per kapita riil (tahun dasar 2005) negara Hongkong sebesar $1 \%$, maka volume ekspor udang putih Indonesia ke negara Hongkong akan menurun sebesar 2,947\%, dengan asumsi cateris paribus. Nilai koefisien pada hasil estimasi sekaligus dapat menunjukkan nilai elastisitas dari variabel GDP per kapita riil (tahun dasar 2005) negara Hongkong. Dari hasil uji $\mathrm{T}$ diperoleh $\mathrm{t}$ hitung sebesar $-2,72$ atau nilai probabilitas sebesar 0,014. Nilai tersebut menunjukkan bahwa variabel GDP per kapita riil (tahun dasar 2005) negara Hongkong memiliki pengaruh yang berbeda nyata terhadap volume ekspor udang putih Indonesia dengan taraf nyata sebesar $10 \%$.

\section{3) Harga Jual Nominal Udang Putih Indonesia ke Negara Hongkong}

Teori ekonomi menyatakan bahwa harga suatu komoditi dan kuantitas yang akan diminta berhubungan secara negatif, cateris paribus (Lipsey et al., 1995). Pada hipotesis penelitian terdapat pengaruh negatif antara harga jual nominal udang putih Indonesia ke negara Hongkong terhadap volume ekspor udang putih Indonesia.

Berdasarkan hasil estimasi model, nilai koefisien variabel harga jual nominal udang putih Indonesia ke negara Hongkong ialah sebesar -1,3828. Nilai tersebut mengindikasikan bahwa harga jual nominal udang putih Indonesia ke negara Hongkong memiliki pengaruh yang negatif terhadap volume ekspor udang putih Indonesia. Nilai koefisien variabel harga jual nominal udang putih Indonesia ke negara Hongkong pada hasil estimasi sesuai dengan hipotesis penelitian. Koefisien tersebut sekaligus dapat menunjukkan nilai elastisitas dari variabel harga jual nominal udang putih Indonesia ke negara Hongkong.

Nilai koefisien yang dimiliki variabel harga jual nominal udang putih Indonesia ke negara Hongkong sebesar 1,3828 dapat diartikan bahwa peningkatan harga jual nominal udang putih Indonesia ke negara Hongkong sebesar 1\%, maka volume ekspor udang putih Indonesia ke negara Hongkong akan menurun sebesar 1,3828\%, dengan asumsi cateris paribus. Hasil uji model dengan uji $\mathrm{T}$, diperoleh $\mathrm{t}$ hitung sebesar $-8,98$ atau nilai probabilitas sebesar 0,000 . Variabel harga jual nominal udang putih Indonesia ke negara Hongkong memiliki pengaruh yang berbeda nyata terhadap volume ekspor udang putih Indonesia dengan taraf nyata sebesar $10 \%$.

\section{4) Harga Jual Nominal Udang Putih Negara Pesaing}

Menurut Lipsey et al. (1995), harga dan kuantitas permintaan suatu komoditi berhubungan secara negatif. Artinya semakin tinggi harga suatu komoditi maka jumlah permintaan terhadap komoditi tersebut akan 
semakin berkurang, cateris paribus. Apabila harga jual negara pesaing tinggi maka permintaan ekspor negara Hongkong dari negara pesaing tersebut akan menurun sedangkan permintaan ekspornya dari negara Indonesia meningkat karena harga udang putih Indonesia lebih murah dibandingkan harga udang putih negara pesaing. Hal ini berarti terdapat pengaruh positif antara variabel harga jual nominal udang putih negara pesaing ke negara Hongkong terhadap volume ekspor udang putih Indonesia.

Berdasarkan hasil estimasi model, nilai koefisien variabel harga jual nominal udang putih negara pesaing ke negara Hongkong ialah sebesar -0,2977. Nilai tersebut mengindikasikan bahwa harga jual nominal udang putih negara pesaing ke negara Hongkong memiliki pengaruh yang negatif terhadap volume ekspor udang putih Indonesia. Nilai koefisien variabel harga jual nominal udang putih negara pesaing ke negara Hongkong pada hasil estimasi tidak sesuai dengan hipotesis penelitian. Koefisien tersebut sekaligus dapat menunjukkan nilai elastisitas dari variabel harga jual nominal udang putih negara pesaing ke negara Hongkong.

Adanya ketidaksesuaian antara hasil estimasi dengan hipotesis penelitian dipengaruhi oleh jenis udang putih negara pesaing yang bersifat inelastis bagi negara Hongkong. Permintaan inelastis negara Hongkong terhadap udang putih negara pesaing merupakan penyebab volume ekspor udang putih dari negara pesaing tersebut tidak menurun. Fluktuasi pada harga jual nominal udang putih negara pesaing selama periode observasi tidak mempengaruhi besarnya permintaan negara Hongkong sehingga negara Hongkong akan tetap membeli udang putih dari negara pesaing meskipun harga tinggi.
Permintaan negara Hongkong yang tetap terhadap udang putih negara pesaing berimplikasi pada volume ekspor udang putih Indonesia yang menurun. Selain itu, negara Singapura yang menjadi salah satu negara pesaing memiliki infrastruktur dan teknik distribusi yang lebih modern dibandingkan negara Indonesia. Pada saat udang putih Singapura tiba di pelabuhan atau distributor induk negara Hongkong, kualitas udang putih negara Singapura masih terjaga dengan baik sehingga kecenderungan permintaan ekspor sangat tinggi.

Nilai koefisien yang dimiliki variabel harga jual nominal udang putih negara pesaing ke negara Hongkong sebesar -0,2977 dapat diartikan bahwa peningkatan harga jual nominal udang putih negara pesaing ke negara Hongkong sebesar 1\%, maka volume ekspor udang putih Indonesia ke negara Hongkong akan menurun sebesar 0,2977\%, dengan asumsi cateris paribus. Hasil uji model dengan uji T, diperoleh $\mathrm{t}$ hitung sebesar -2,02 atau nilai probabilitas sebesar 0,059 . Variabel harga jual nominal udang putih negara pesaing ke negara Hongkong memiliki pengaruh yang berbeda nyata terhadap volume ekspor udang putih Indonesia dengan taraf nyata sebesar $10 \%$.

\section{5) Kurs Nominal Negara Indonesia Terhadap Negara Hongkong}

Menurut Mankiw (2006), jika kurs tinggi maka barang-barang luar negeri relatif lebih murah dan barang-barang domestik relatif lebih mahal. Pada saat nilai kurs rendah, barang-barang luar negeri relatif lebih mahal dan barangbarang domestik relatif lebih murah. Dalam hal ini, apresiasi rupiah Indonesia terhadap dolar Hongkong akan menurunkan volume ekspor udang putih Indonesia ke negara Hongkong, 
demikian sebaliknya. Terjadinya depresiasi rupiah Indonesia terhadap dolar Hongkong akan meningkatkan volume ekspor udang putih Indonesia ke negara Hongkong. Nilai tukar nominal negara Indonesia terhadap negara Hongkong berpengaruh positif terhadap volume ekspor udang putih Indonesia.

Dari hipotesis penelitian terdapat pengaruh positif antara kurs nominal negara Indonesia terhadap negara Hongkong dengan volume ekspor udang putih Indonesia. Berdasarkan hasil estimasi model, nilai koefisien variabel kurs nominal negara Indonesia terhadap negara Hongkong ialah sebesar $-3,871$. Nilai koefisien pada hasil estimasi tersebut mengindikasikan bahwa variabel kurs nominal negara Indonesia terhadap negara Hongkong memiliki pengaruh yang negatif terhadap volume ekspor udang putih Indonesia. Hal tersebut mengindikasikan bahwa nilai koefisien pada variabel kurs nominal negara Indonesia terhadap negara Hongkong tidak sesuai dengan hipotesis penelitian. Koefisien tersebut sekaligus menunjukkan nilai elastisitas dari variabel kurs nominal negara Indonesia terhadap negara Hongkong.

Ketidaksesuaian antara nilai koefisien variabel kurs nominal negara Indonesia terhadap negara Hongkong pada hasil estimasi dengan hipotesis penelitian disebabkan oleh harga internasional, kebijakan nilai tukar uang, kuota ekspor dan impor serta kebijakan tarif dan non tarif (Raharjo 2001). Indikasi adanya penetapan harga kontrak udang putih Indonesia dengan negara Hongkong akan berdampak terhadap volume ekspor udang putih Indonesia. Pada saat terjadi apresiasi mata uang rupiah terhadap dolar Hongkong, negara yang melakukan perdagangan tetap menggunakan harga yang telah disepakati bersama dalam perjanjian perdagangan. Hal tersebut mengakibatkan kemampuan negara Hongkong membeli udang putih Indonesia menjadi lebih rendah karena pada saat yang bersamaan negara Hongkong mengalami depresiasi terhadap mata uangnya, demikian sebaliknya.

Produksi udang putih Indonesia dalam jangka pendek memiliki rentan waktu yang lambat, karena budi daya udang putih Indonesia masih menggunakan cara tradisional. Pada saat produksi udang putih Indonesia menurun, maka anggota ASEAN dari negara lain, seperti: Malaysia, Thailand dan Filipina dapat menggantikan besarnya permintaan udang putih negara Hongkong dari negara Indonesia. Terjadinya depresiasi nilai tukar rupiah Indonesia terhadap dolar Hongkong diikuti dengan lambatnya produksi udang putih Indonesia dalam jangka pendek. Hal tersebut mengindikasikan bahwa besarnya volume ekspor udang putih Indonesia menurun pada saat terjadinya depresiasi nilai tukar rupiah Indonesia dengan dolar Hongkong.

Berdasarkan trade policy review negara Hongkong mengenai jasa keuangannya yang termuat dalam World Trade Organization (2014), untuk memperkuat daya saing negara Hongkong dalam menghadapi tingginya persaingan global dan untuk mempertahankan posisi negara tersebut sebagai pusat keuangan regional dan internasional terkemuka, negara Hongkong akan terus meningkatkan kualitas pasar seperti menerapkan pengujian dan sertifikasi produk, memodernisasi rezim peraturan serta meningkatkan infrastruktur pasar. Pada umumnya, budi daya udang putih Indonesia masih menggunakan cara tradisional yang sederhana sehingga tidak bisa mengikuti standar produk yang ditetapkan oleh negara Hongkong. Hal tersebut mengakibatkan penurunan 
volume ekspor udang putih Indonesia ke negara Hongkong.

Koefisien yang dimiliki variabel kurs nominal negara Indonesia terhadap negara Hongkong sebesar -3,871 dapat diartikan bahwa peningkatan kurs nominal negara Indonesia terhadap negara Hongkong sebesar 1\%, maka volume ekspor udang putih Indonesia ke negara Hongkong akan menurun sebesar 3,871\%, dengan asumsi cateris paribus. Pengujian yang dilakukan dengan uji T diperoleh $\mathrm{t}$ hitung sebesar -1,98 atau nilai probabilitas sebesar 0,064 . Variabel kurs nominal negara Indonesia terhadap negara Hongkong memiliki pengaruh yang berbeda nyata terhadap volume ekspor udang putih Indonesia dengan taraf nyata sebesar $10 \%$.

\section{6) Krisis Ekonomi Negara Indonesia Tahun 1997/1998}

Menurut Tarmidi (1999), krisis ekonomi tahun 1998 dipicu oleh nilai tukar rupiah yang mengalami depresiasi sehingga cadangan devisa tidak mampu membayar tagihan utang swasta yang sudah jatuh tempo karena terjadi defisit pada neraca berjalan. Krisis ekonomi yang terjadi pada tahun 1998 juga dipicu oleh kelemahan pada sistem perbankan Indonesia sehingga berimplikasi terhadap depresiasi nilai mata uang rupiah. Terjadinya depresiasi rupiah akibat krisis ekonomi memiliki pengaruh yang positif terhadap volume ekspor udang putih Indonesia ke negara Hongkong. Depresiasi rupiah menyebabkan harga udang putih Indonesia relatif lebih murah dibandingkan negara lainnya sehingga permintaan ekspor udang putih Indonesia oleh negara Hongkong meningkat.

Berdasarkan hasil estimasi model, nilai koefisien variabel krisis ekonomi Indonesia tahun 1998 (dummy) ialah sebesar 5,080. Nilai tersebut mengindikasikan bahwa variabel krisis ekonomi Indonesia tahun 1998 (dummy) memiliki pengaruh yang positif terhadap volume ekspor udang putih Indonesia. Nilai koefisien variabel krisis ekonomi Indonesia tahun 1998 (dummy) pada hasil estimasi sesuai dengan hipotesis penelitian. Koefisien tersebut sekaligus dapat menunjukkan nilai elastisitas dari variabel krisis ekonomi Indonesia tahun 1998 (dummy).

Nilai koefisien yang dimiliki variabel krisis ekonomi Indonesia tahun 1998 (dummy) sebesar 5,080 dapat diartikan bahwa peningkatan goncangan krisis ekonomi Indonesia tahun 1998 (dummy) sebesar 1\%, maka volume ekspor udang putih Indonesia ke negara Hongkong akan meningkat sebesar $5,080 \%$, dengan asumsi cateris paribus. Hasil uji model dengan uji $\mathrm{T}$, diperoleh $\mathrm{t}$ hitung sebesar 2,33 atau nilai probabilitas sebesar 0,032 maka variabel krisis ekonomi Indonesia tahun 1998 (dummy) memiliki pengaruh yang berbeda nyata terhadap volume ekspor udang putih Indonesia dengan taraf nyata sebesar $10 \%$.

\section{Implikasi Kebijakan}

Rancangan strategi Kementerian Kelautan dan Perikanan (KKP) pada periode 2010 sampai tahun 2014 adalah peningkatan produksi perikanan budi daya $353 \%$ pada tahun 2014. Berdasarkan program revitalisasi perikanan budi daya, udang ditempatkan sebagai komoditas unggulan selain rumput laut dan tuna. Hal ini cukup beralasan karena komoditas tersebut merupakan komoditas ekspor dan teknologinya sudah mulai berkembang di masyarakat.

Setelah dilakukan analisis model dengan pendekatan teoritis dan deskriptif, maka diperoleh beberapa kebijakan guna meningkatkan ekspor 
udang putih Indonesia ke negara Hongkong pada waktu yang akan datang. Apabila udang putih Indonesia diasumsikan sebagai barang normal maka langkah strategis yang dapat dilakukan pemerintah ialah menurunkan harga jual udang putih Indonesia agar rata-rata dari total biaya produksi menurun sehingga mencapai economies of scale. Selain itu peningkatan total produksi dapat diperoleh dari efisiensi yang dilakukan terhadap faktor-faktor produksinya. Kebijakan ini juga disesuaikan dengan beberapa teori ekonomi dan penelitian terdahulu sehingga dirumuskan menjadi suatu kebijakan penting dalam meningkatkan volume ekspor udang putih Indonesia ke dunia, khususnya ke negara tujuan utama ekspor yaitu Hongkong. Peningkatan total produksi udang putih Indonesia dapat diupayakan dengan beberapa langkah strategis berikut.

\section{1) Pemanfaatan lahan budi daya udang putih}

Bertambahnya total populasi negara Hongkong setiap tahunnya akan meningkatkan permintaannya terhadap ekspor udang putih Indonesia. Permintaan negara Hongkong terhadap ekspor udang putih Indonesia dapat dipenuhi dengan meningkatkan kualitas dan produksi udang putih domestik Indonesia. Potensi pembudidayaan udang putih di negara Indonesia sangat besar, tetapi pemanfaatannya belum maksimal sehingga perlu peningkatan pemanfaatan lahan budi daya guna meningkatkan produksi udang putih. Peluang udang putih dikembangbiakan sangat besar sekitar $75,64 \%$ sampai $98,57 \%$ dari potensi lahan masingmasing jenis budi daya udang putih yang tersedia, seperti yang tercantum pada Lampiran 4.

Jenis budi daya udang putih tambak memiliki peluang pengembang- an sebesar $77,82 \%$ dari potensi lahannya. Demikian halnya dengan jenis budi daya udang putih kolam yang memiliki peluang pengembangan sebesar $75,64 \%$ dari potensi lahannya. Jenis budi daya udang putih perairan umum memiliki peluang pengembangan paling besar dibandingkan jenis budi daya udang putih lainnya. Peluang jenis budi dayanya sebesar $98,86 \%$ dari besar potensi lahannya. Berbeda dengan besarnya peluang pengembangan jenis budi daya udang putih pada lahan mina padi yang mencapai $89,83 \%$ dari besarnya potensi lahan yang tersedia sedangkan jenis lahan budi daya udang putih laut memiliki peluang pengembangan sebesar $98,57 \%$ dari besarnya potensi lahan yang tersedia (KKP, 2013).

\section{2) Kredit dana perbankan}

Dalam proses produksi dibutuhkan faktor-faktor produksi berupa alat atau sarana. Lipsey et al. (1995) mengatakan bahwa faktor produksi adalah sumber daya yang digunakan dalam memproduksi barang atau jasa untuk memenuhi kebutuhan, seringkali terdiri dari kategori dasar yaitu: lahan, tenaga kerja dan modal.

Berdasarkan Dirjen Perikanan Budi daya dalam KKP (2014), tahun 2015 sampai tahun 2019 merupakan target capaian produksi perikanan budi daya yaitu sebesar 33.036 juta ton. Target produksi perikanan budi daya tersebut perlu didukung oleh beberapa faktor diantaranya: lahan dan prasaranasarana, investasi dan pembiayaan usaha, input produksi (pakan, benih, induk obat ikan, dll), adopsi teknologi serta menguatkan kelembagaan POKDAKAN (kelompok pembudidaya ikan), gapokan dan asosiasi.

Pada umumnya, nelayan udang putih Indonesia masih menggunakan peralatan yang sederhana dan tradisional 
dalam pembudidayaan udang putih. Keterbatasan modal berdampak terhadap minimnya skala usaha yang dimiliki oleh para nelayan udang putih sehingga pengembangan usaha masih sulit dilakukan. Pengoptimalan penyerapan kredit bersubsidi bagi peralatan maupun modal usaha dalam upaya meningkatkan skala budi daya udang putih Indonesia sangat diperlukan.

Adanya kesepakatan bersama antara Kementerian Kelautan dan Perikanan dengan PT. Bank Rakyat Indonesia (Persero) Tbk yang telah ditandatangani pada tanggal 7 Februari 2012 mengenai Penyediaan dan Penggunaan Jasa Perbankan hanya dapat dijangkau oleh para nelayan di daerah yang sudah maju dan dekat dengan wilayah perkotaan. Penyediaan jasa perbankan tersebut belum merata karena tidak dapat dinikmati oleh para nelayan yang berada di pelosok atau daerah terpencil namun yang kaya dengan sumber daya alamnya. Pemerataan bantuan dan jasa perbankan perlu dilakukan agar memacu peningkatan produksi udang putih Indonesia melalui jasa layanan yang disediakan, seperti: Bantuan Langsung Masyarakat (BLM), Kredit Usaha Rakyat (KUR) serta Kredit Ketahanan Pangan dan Energi (KKPE) sehingga berimplikasi terhadap bertambahnya produksi dalam negeri dan skala usaha yang semakin meningkat.

\section{3) Kebijakan pasar, tarif ekspor dan stabilisasi harga udang putih}

Harga jual nominal udang putih dan nilai tukar negara Indonesia terhadap negara Hongkong memiliki pengaruh terhadap besarnya volume ekspor udang putih Indonesia. Pengaturan penawaran udang putih (supply) dengan permintaan udang putih Indonesia (demand) dapat menjadi alternatif kebijakan pasar. Kebijakan pasar merupakan kebijakan yang mengarah pada pemerintah, sehingga untuk memenuhi permintaan ekspor udang putih Indonesia dari negara Hongkong (importir) dapat dilakukan dengan mempertahankan atau meningkatkan jumlah produksi nasional.

Pemerintah diharapkan dapat meningkatkan kapasitas ekspor udang putih ke negara Hongkong melalui pengurangan tarif ekspor yang lebih efektif terkait adanya kerjasama perdagangan antara negara Indonesia dan negara Hongkong dalam perjanjian ACFTA. Peningkatan harga jual udang putih Indonesia ke negara Hongkong tidak mendorong pertumbuhan budi daya udang putih di Indonesia yang cenderung bersifat sederhana dan tradisional sehingga penurunan biaya produksi perlu dilakukan agar menurunkan harga jualnya ke negara Hongkong.

\section{4) Membangun kemitraan usaha yang berkelanjutan}

Berdasarkan KKP (2014), adanya keterbatasan sumber daya dalam melakukan implementasi kebijakan industrialisasi perikanan sehingga yang perlu dilakukan oleh pemerintah adalah membuka diri bagi keterlibatan pihakpihak terkait khususnya pihak swasta, perbankkan, perguruan tinggi dan organisasi perikanan serta stakeholders lain dalam melaksanakan dan mengawal secara langsung pelaksanaan industrialisasi perikanan budi daya di negara Indonesia. Berdasarkan keterbatasan tersebut pemerintah perlu mengambil langkah dengan meningkatkan pengembangan program kemitraan yang melibatkan perusahaanperusahaan besar maupun Badan Usaha Milik Negara (BUMN) melalui program CSR (Corporate Social Responsibility) yang dapat dilakukan dengan berbagai 
pola seperti: community development, peningkatan kapasitas, promosi produk dan perkuatan permodalan bagi Usaha Mikro dan Kecil.

Upaya yang harus dilakukan oleh pemerintah untuk mendorong pengembangan kemitraan antara lain: memfasilitasi atau mengadvokasi pengembangan kemitraan, mengeluarkan kebijakan dalam mendorong program kemitraan, melakukan pengawalan dan evaluasi secara periodik, penerapan kebijakan secara konsisten baik di tingkat pusat maupun daerah serta memberikan reward bagi perusahaan yang berprestasi dalam mengembangkan dan memperkuat UMKM di negara Indonesia. Berdasarkan kebijakan tersebut, pencapaian target produksi serta peningkatan total produksi udang putih Indonesia dapat direalisasikan sehingga memberikan dampak terhadap penambahan devisa negara.

\section{KESIMPULAN DAN SARAN}

\section{Kesimpulan}

Faktor-faktor yang mempengaruhi volume ekspor udang putih Indonesia ke negara Hongkong ialah: variabel total populasi negara Hongkong, GDP per kapita riil (tahun dasar 2005) negara Hongkong, harga jual nominal udang putih Indonesia ke negara Hongkong, harga jual nominal udang putih negara pesaing ke negara Hongkong, kurs nominal negara Indonesia terhadap negara Hongkong dan krisis ekonomi negara Indonesia tahun 1998 sebagai variabel dummy. Berdasarkan hasil estimasi model, semua variabel independen yang digunakan memiliki pengaruh yang berbeda nyata terhadap volume ekspor udang putih Indonesia dengan taraf nyata sebesar $10 \%$.
Adapun variabel yang dimaksud yaitu: variabel total populasi negara Hongkong yang memiliki pengaruh positif, GDP per kapita riil (tahun dasar 2005) negara Hongkong yang berpengaruh negatif, harga jual nominal udang putih Indonesia ke negara Hongkong yang memiliki pengaruh negatif, harga jual nominal udang putih negara pesaing ke negara Hongkong yang memiliki pengaruh negatif, kurs nominal negara Indonesia terhadap negara Hongkong dengan pengaruh negatif dan variabel dummy yaitu krisis ekonomi Indonesia pada tahun 1998 yang berpengaruh positif terhadap volume ekspor udang putih Indonesia dengan taraf nyata sebesar $10 \%$. Kebijakan yang disarankan untuk peningkatan volume ekspor udang putih Indonesia ke negara Hongkong ialah: pemanfaatan lahan budi daya udang putih, kredit dana perbankan, kebijakan pasar, tarif ekspor dan stabilisasi harga udang putih Indonesia serta membangun kemitraan usaha yang berkelanjutan.

\section{Saran}

1) Pemerintah perlu mengoptimalkan program-program yang telah berjalan dengan melakukan pemantauan serta evaluasi secara periodik dan melindungi kawasan tambak udang putih agar tidak beralih fungsi ke sektor lain. Selain itu, pemerintah dapat menurunkan harga jual udang putih Indonesia melalui pengurangan rata-rata dari total biaya produksinya dengan melakukan efisiensi pada faktorfaktor produksi udang putih seperti pengoptimalan penyediaan jasa layanan kredit subsidi, membangun pola kemitraan dan melakukan kebijakan pasar maupun tarif ekspor impor. 
2) Nelayan perlu mengoptimalkan penyerapan penggunaan jasa layanan yang sudah disediakan oleh pemerintah sehingga meningkatkan total produksi udang putih. Selain itu, untuk bersinergi dengan penurunan harga jual udang putih Indonesia, nelayan dapat memperbaiki metode pemeliharaan dengan meningkatkan efisiensi proses produksi melalui pemanfaatan potensi lahan budi daya yang tersedia sehingga mengurangi rata-rata biaya produksinya.

\section{DAFTAR PUSTAKA}

Gujarati, DN. 2006. Basic Econometric. Edisi ke-4. New York (US): Mc Graw Hill.

Juanda, B. 2009. Ekonometrika Pemodelan dan Pendugaan. Bogor (ID): IPB Press.

[KKP] Kementerian Kelautan dan Perikanan. 2013. Potensi Lahan Budidaya dan Tingkat Pemanfaatannya di Indonesia. http://www.kkp.org [22 Januari 2015].

Lipsey RG, Courant PN, Steiner P. 1995. Pengantar Ilmu Mikroekonomi. J. Wasana. Kirbrandoko. penerjemah. Jakarta (ID): Binarupa Aksara.

Mankiw GN. 2006. Makroekonomi. Fitria Liza. Imam Nurmawan. penerjemah. Jakarta (ID): Erlangga.

Oktariza W. 2000. Analisis Ekonomi Perkembangan Pasar EksporImpor Udang Antar 4 Negara Asean 2006. Tesis. Program Pascasarjana, Institut Pertanian Bogor, Bogor.

Raharjo A. 2001. Dampak Perubahan Faktor Ekonomi terhadap Perdagangan Udang Indonesia di Pasar Domestik dan Internasional. Tesis. Program Pascasarjana, Institut Pertanian Bogor, Bogor.

Tarmidi L. 1999. Krisis Moneter Indonesia: Sebab, Dampak, Peran IMF dan Saran. Jakarta: Buletin Ekonomi Moneter dan Perbankan.

[UN COMTRADE] United Nations Commodity Trade Statistics Database. 2013. Data query of export and import. http://comtrade.un.org [6 Oktober 2014]

[Worldbank]. 2013. World Bank Data Bank. [internet]. [diunduh 6 Oktober 2014]. Tersedia di: http://databank.worldbank.org

[WTO]. 2014. World Trade Organization. http://www.wto.org [11 Juni 2015]

Yuniarti D. 2007. Analisis Determinasi Perdagangan Bilateral Indonesia Pendekatan Gravity Model. JEKP. 12(2): 99-109. 